\title{
STUDI KUALITAS AIR SUNGAI CISADANE KOTA TANGERANG DITINJAU DARI PARAMETER FISIKA
}

\author{
Desy Rosarina ${ }^{1}$ dan Ellysa Kusuma Laksanawati ${ }^{2}$ \\ ${ }^{1,2}$ Dosen Teknik Industri Universitas Muhammadiyah Tangerang \\ Jalan P. Kemerdekaan No.33 Cikokol Kec. Tangerang Kota Tangerang 15118 \\ Email :desy.rosarina@umt.ac.id
}

\begin{abstract}
ABSTRAK
Penelitian yang mengkaji kualitas air Sungai Cisadane Kota Tangerang berdasarkan parameter fisika telah dilaksanakan pada bulan April sampai Agustus 2018.Penelitian menggunakan metode survey, dengan pengambilan sampel air dilakukan secara purposive sampling, yaitu pengambilan sampel dilakukan dengan memperhatikan berbagai pertimbangan kondisi serta keadaan daerah pengamatan, dengan menentukan 3 stasiun pengamatan, yaitu di kawasan taman kota (stasiun1), kawasan perumahan (stasiun 2) dan kawasan pabrik (stasiun 3). Pengambilan sampel dilakukan secara komposit di setiap stasiun. Analisis yang dilakukan menggunakan dua cara, yakni analisis secara insitu, yaitu analisis sampel yang dilakukan langsung di lokasi pengamatan dan analisis secara eksitu, yaitu analisis yang dilakukan di laboratorium. Parameter fisika yang diamati yaitu suhu, TDS, TSS, warna dan bau serta kecerahan. Hasil penelitian menunjukkan bahwa kualitas air di sungai Cisadane Kota Tangerang masih memenuhi Baku Mutu Air kelas II berdasarkan PP No. 82 tahun 2001 yaitu suhu dengan rata-rata $28,57^{\circ} \mathrm{C}$, TDS dengan nilai rata-rata $55,67 \mathrm{mg} / \mathrm{L}$, TSS dengan rata-rata $26,33 \mathrm{mg} / \mathrm{L}$, warna agak keruh sampai keruh, bau dari agak berbau sampai menyengat dan kecerahan dengan nilai rata-rata $7,7 \mathrm{~cm}$.
\end{abstract}

Kata Kunci : baku mutu air, kualitas air, Sungai Cisadane

\section{PENDAHULUAN}

Air adalah zat atau materi atau unsur yang penting bagi semua bentuk kehidupan yang diketahui sampai saat ini di bumi, tetapi tidak di planet lain. Air menutupi hampir $71 \%$ permukaan bumi. Terdapat 1,4 triliun kubik (330 juta mil3) tersedia di bumi. Kualitas air dapat diukur berdasarkan berbagai parameter air baik fisika, biologi dan kimia. Dari segi parameter fisika yaitu suhu, tingkat kecerahan, tingkat kekeruhan dan tingkat kedalaman,.Parameter kimia yaitu $\mathrm{pH}, \mathrm{O}_{2}$ terlarut dan $\mathrm{CO}_{2}$ bebas, sedangkan untuk parameter biologi yaitu ikan. Pengukuran kualitas air dilakukan pada ekosistem perairan seperti kolam waduk, sungai, laut, danau, teluk, delta, semenanjung dan perairan lainnya.

Sungai Cisadane adalah salah satu sungai besar di Tatar Pasundan, Pulau Jawa, yang bermuara ke Laut Jawa. Hulu sungai ini berada di lereng Gunung Pangrango, dengan anak sungai yang berawal di G. Salak, melintas di sisi barat Kabupaten Bogor, ke arah Kabupaten Tangerang dan bermuara di sekitar Tanjung Burung. Dengan panjang keseluruhan sekitar $126 \mathrm{~km}$, sungai ini melintasi 44 kecamatan di Kabupaten Bogor, Kota Bogor, Kabupaten Tangerang, Kota Tangerang, dan Tangerang Selatan(Wikipedia, 2016).

Sungai Cisadane telah mengalami dapak akibat perubahan tata guna lahan. Selain menjadikawasan pemukiman, taman kota, juga menjadi jalur transportasi dengan perahu kecil untuk menyebrangkan warga dari tepian yang satu ke tepian yang lain. Para nelayan juga bisa mengambil kekayaan sungai 
untuk mencari ikan. Kesemua aktivitas tersebut mempengaruhi kualitas air dan mempunyai petensi mencemari perairan di sungai Cisadane, yang berdampak pada menurunnya kualitas air. Menurut Tajangenyasha dan Dzinomwa dalam Agustiningsih et al. (2012), perubahan kondisi kualitas air sungai merupakan dampak dari buangan kegiatan industri dan pemukiman di sekitar daerah aliran sungai.

Dari informasi tersebut, kajian kualitas perairansungai Cisadane perlu dilakukan untuk mengetahui kualitas air melalui sifat fisikanya, sehingga dapat memberikan informasi tentang suhu, TDS, TSS, warna, baud an kecerahan, sehingga dapat memberikan kontribusi bagi pembangunan dan pengembangan ilmu pengetahuan.

\section{METODE PENELITIAN}

\section{Waktu dan Tempat Penelitian}

Penelitian ini akan dilaksanakan pada Bulan Februari sampai November 2018 berlokasi di perairan Sungai Cisadane Kota Tangerang. Sedangkan analisa kualitas air dilakukan di UPTD Laboratorium Lingkungan Dinas Lingkungan Hidup dan Kebersihan Kabupaten Tangerang.

\section{Metode Penelitian}

Penelitian menggunakan metode survey. Pengambilan sampel dilakukan secara purpossive sampling, mengacu pada penelitian Damarany et al. (2009), Agustiningsih et al. (2012), Sahabuddin et al. (2014) dan Sasongko et al. (2014).Penentuan stasiun pengambilan sampel air ditentukan secara purposive sampling, dengan mempertimbangkan masukan bahan organik ke dalam perairan (Rahman et al., 2016). Stasiun 1 ditentukan pada kawasan taman kota di Taman Gajah Tunggal Cikokol. Stasiun 2 di kawasan perumahan penduduk di wilayah Babakan Cikokol dan stasiun 3 di kawasan pabrik kertas di wilayah Karawaci.

\section{Pengambilan sampel parameter fisika}

Disiapkan botol sampel berukuran $600 \mathrm{ml}$ yang terlebih dahulu telah dibersihkan. Dicelupkan botol tersebut ke dalam air dengan posisi miring dengan mulut botol sampel yang menghadap atau berlawanan arus.Botol sampel yang bermuatan $600 \mathrm{ml}$ ini diberi keterangan setiap pengambilan. Ke dalam botol sampel tersebut diukur suhu, TDS, TSS, kecerahan, warna dan bau. Pengambilan sampel ini diulang 3 kali, setelah itu dikomposit dan sampel air disimpan ke dalam lemari pendingin/kulkas yang disediakan di laboratorium.

\section{Analisis Data}

Data dianalisis di UPTD Laboratorium Lingkungan Dinas Lingkungan Hidup dan Kebersihan Kabupaten Tangerang, secara deksriptif dengan membandingkan hasil uji laboratorium dengan baku mutu air sesuai dengan PP No 82/2001 untuk peruntukan kelas II.

\section{HASIL DAN PEMBAHASAN Suhu}

Suhu merupakan faktor penting dalam keberlangsungan proses biologi dan kimia yang terjadi di dalam air, seperti kehidupan dan perkembangbiakan organisme air.Suhu mempengaruhi kandungan oksigen di dalam air, proses fotosintesis tumbuhan air, laju metabolisme organisme air dan kepekaan organisme terhadap polusi, parasit dan penyakit.Hasil pengukuran suhu dapat dilihat pada gambar $1 \mathrm{di}$ bawah ini. 


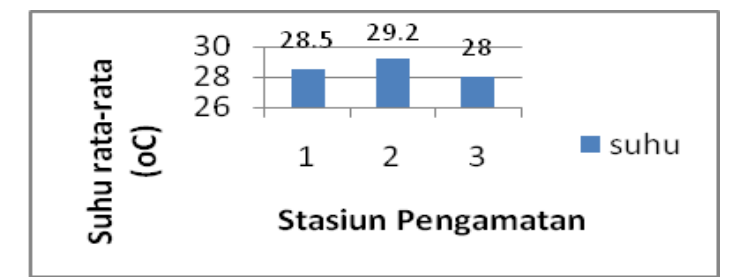

Gambar 1. Hasil Pengukuran Parameter Suhu Air

Gambar 1. menunjukkan nilai suhu tertinggi terdapat pada stasiun 2 sebesar $29,2^{\circ} \mathrm{C}$ sedangkan nilai suhu terendah terdapat pada stasiun 3 yaitu sebesar $28^{\circ} \mathrm{C}$. Tingginya suhu di stasiun 2 diduga disebakan kawasan tersebut merupakan pemukiman yang merupakan daerah terbuka, jauh dari naungan atau tutupan vegetasi sehingga mempercepat proses serapan sinar matahari ke badan air, dibandingkan dengan stasiun 1 dan 3. Pada kawasan perumahan ini kebanyakan vegetasi dengan tajuk pohon yang besar sudah tidak ada lagi. Pada stasiun 1 yang merupakan kawasan taman kota dan stasiun 3 yang merupakan kawasan pabrik, suhu air sedikit lebih rendah dibandingkan stasiun 1, diduga karena pada dua kawasan ini lebih banyak ternaungi pepohonan di sekitarnya, sehingga memperlambat daya tembus matahari oleh karena itu suhu di daerah tersebut relatif lebih rendah. Suhu yang demikian dianggap cukup baik, karena menurut Nuriya et al. (2010), bahwa kisaran suhu yang optimal bagi kehidupan biota perairan adalah $24^{\circ} \mathrm{C}$ sampai dengan $28^{\circ} \mathrm{C}$.

Meskipun demikian, kondisi suhu di 3 stasiun masih memenuhi baku mutu air kelas II, dan masih tergolong optimum dikarenakan masih sesuai peruntukan berbagai kebutuhan yaitu antara $27^{\circ} \mathrm{C}$ sampai $31^{\circ} \mathrm{C}($ Rahman et al., 2016).

\section{Total Zat Padat Terlarut (Total Dissolved Solid/TDS)}

Total zat padat terlarut merupakan merupakan padatan yang terlarut dalam larutan baik berupa zat organik maupun anorganik, yaitu semua mineral, garam, logam, serta kation-anion yang terlarut di air. Secara umum, konsentrasi benda-benda padat terlarut merupakan jumlah antara kation dan anion didalam air. Hasil analisa TDS dapat dilihat pada gambar 2 dibawah ini :

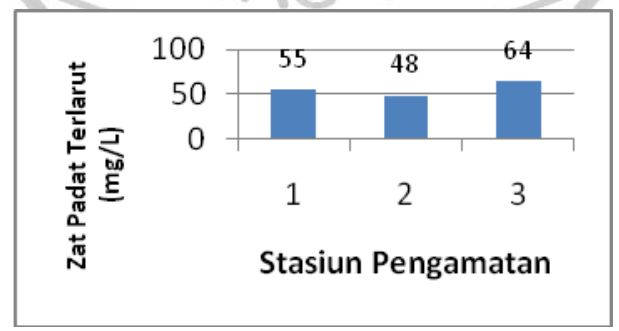

Gambar 2. Hasil Pengukuran TDS (Total Padatan Terlarut) Air

Gambar 2. menunjukkan nilai total padatan terlarut (TDS) di perairan sungai Cisadane di tiga stasiun masih tergolong memenuhi baku mutu air yaitu masih jauh di bawah $1.000 \mathrm{mg} / \mathrm{L}$. Kandungan TDS tertinggi terdapat pada stasiun 3 sebesar $64 \mathrm{mg} / \mathrm{L}$ dan nilai TDS terendah terdapat pada stasiun 2 sebesar $48 \mathrm{mg} / \mathrm{L}$. Tingginya nilai TDS pada stasiun 3 diduga disebabkan dari sumber pencemar dari limbah pabrik, antara lain limbah detergent, bahan-bahan kimia, MCK dan kegiatan pabrik lainnya, sebagaimana yang dikemukakan Mahyudin et al. (2015), biasanya zat padat terlarut tinggi tinggi karena banyaknya zat padat terlarut oleh berbagai aktivitas manusia. Kandungan TDS di kawasan taman kota (stasiun 1) termasuk sedang dibandingkan 2 stasiun lainnya, sebesar $55 \mathrm{mg} / \mathrm{L}$. Meskipun demikian, kualitas air di ketiga stasiun masih terbilang baik bila ditinjau dari kandungan TDS. 


\section{Total Padatan Tersuspensi (Total Suspended Solid/ TSS)}

Total padatan tersuspensi (TSS) merupakan merupakan padatan yang terdapat pada larutan namun tidak terlarut, dapat menyebabkan larutan menjadi keruh, dan tidak dapat langsung mengendap pada dasar larutan antara lain lumpur, tanah liat, logam oksida, sulfida, ganggang, bakteri dan jamur. TSS memberikan konstribusi untuk kekeruhan (turbidity) dengan membatasi penetrasi cahaya untuk fotosintesis dan visibilitas di perairan.Hasil pengukuran TSS di tiga stasiun ditampilkan pada gambar 3 di bawah ini.

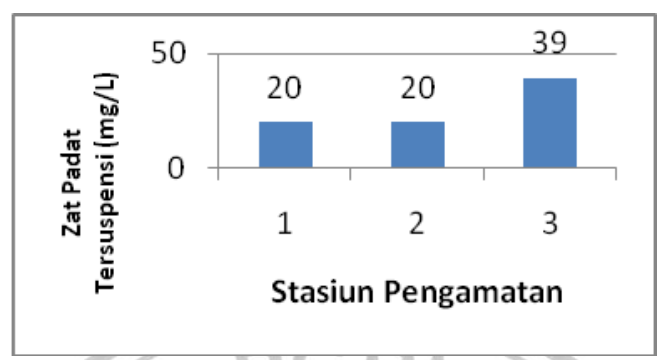

Gambar 3. Hasil Pengukuran TSS (Total Padatan Terlarut) Air

Kandungan TSS tertinggi ada pada stasiun 3 sebesar $39 \mathrm{mg} / \mathrm{L}$, sedangkan pada stasiun 1 dan 2 hanya sebesar $20 \mathrm{mg} / \mathrm{L}$. Tingginya kandungan TSS di stasiun 3 diduga disebabkan karena aktifitas di wilayah ini yang merupakan kawasan pabrik kertas yang memberikan kontribusi masukan bahan organik ke sungai yang lebih banyak. Hal yang sama juga dikemukakan Djoharan et al. (2018) bahwa kisaran TSS 20-110 mg/L masih cukup baik, sehingga kandungan TSS di ketiga stasiun masih memenuhi standard baku mutu air kelas II.

\section{Warna dan Bau}

Warna dan bau merupakan faktor fisik yang berhubungan dengan/kandungan air, antara lain berkaitan dengan kandungan TSS dan BOD. Hasil pengamatan warna dapat dilihat pada Tabelldibawah ini :

Tabel 1.Hasil Pengamatan Warna dan Bau di 3 Stasiun Pengamatan.

\begin{tabular}{|c|c|c|}
\hline \multirow{2}{*}{ Tempat Pengambilan Sampel } & \multicolumn{2}{|c|}{ Hasil Pengukuran } \\
\cline { 2 - 3 } & Warna & Bau \\
\hline Stasiun 1 & Agak keruh & Agak berbau \\
\hline Stasiun 2 & Keruh & Bau menyengat \\
\hline Stasiun 3 & Keruh & Bau menyengat \\
\hline
\end{tabular}

Tabel 1. menunjukkan bahwa warna secara umum pada setiap stasiun adalah keruh. Warna keruh diduga disebabkan karena kandungan zat padat tersuspensi yang hampir mencapai nilai setengah baku mutu air. Keruhnya air disebabkan oleh karena letak stasiun tersebut merupakan aliran air yang berasal dari limbah rumah tangga dan pabrik yang mengandung banyak bahan kimia, sabun, minyak sehingga warna air menjadi keruh.Warna air menunjukkan material yang terkandung dalam air dapat berupa jumlah zat tersuspensi (TDS).Faktor lainnya adalah beberapa jenis plankton, larutan tersuspensi, dekomposisi bahan organik, mineral ataupun bahan-bahan lain yang terlarut dalam air (Nuriya et al.,2010). 


\section{Kecerahan}

Kecerahan merupakan parameter fisika yang erat kaitannya dengan proses fotosintesis pada suatu ekosistem perairan. Kecerahan menggambarkan sejumlah atau sebagian cahaya yang diteruskan pada kedalaman tertentu. Hasil pengukuran kecerahan dapat dilihat pada gambar 4 di bawah ini:

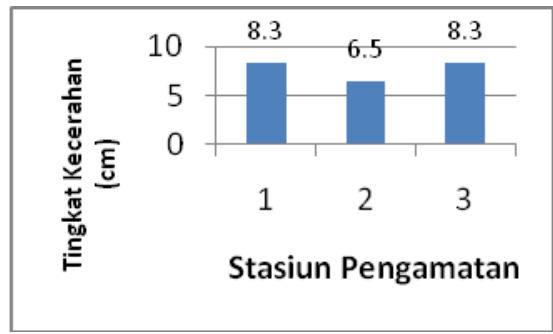

Gambar 4. Hasil Pengukuran Kecerahan Air

Menurut Nuriya et al., (2010), tingkat kecerahan yang baik untuk kehidupan organisme air 30 sampai dengan $40 \mathrm{~cm}$ atau lebih. Apabila kecerahan kurang dari $25 \mathrm{~cm}$, maka pergantian air harus cepat dilakukan sebelum fitoplankton mati berurutan yang diikuti penurunan oksigen terlarut secara drastis. Kecerahan yang tinggi menunjukkan daya tembus cahaya matahari yang jauh ke dalam perairan.Begitu juga sebaliknya.Apabila kecerahan tidak baik, berarti perairan itu keruh.Kekeruhan (turbidity) air sangat berpengaruh terhadap kehidupan biota perairan.

\section{KESIMPULAN}

Berdasarkan hasil penelitian dapat disimpulkan bahwa kualitas air Sungai Cisadane Kota Tangerang berdasarkan sifat fisikanya masih memenuhi baku mutu lingkungan kelas II berdasarkan PP No. 82 tahun 2001 yaitusuhu dengan rata-rata $28,57^{\circ} \mathrm{C}$, TDS dengan nilai rata-rata $55,67 \mathrm{mg} / \mathrm{L}$, TSS dengan rata-rata $26,33 \mathrm{mg} / \mathrm{L}$, warna agak keruh sampai keruh, bau dari agak berbau sampai menyengat dan kecerahan dengan nilai rata-rata $7,7 \mathrm{~cm}$.

\section{DAFTAR PUSTAKA}

Agustiningsih, D.,S.B.Sasongko dan Sudarno. 2012. Analisis Kualitas Air dan Strategi Pengendalian Pencemaran Air Sungai Blukar Kabupaten Kendal.Jurnal Presipitasi. Volume 9 No 2 September 2012. Universitas Diponegoro.Semarang. http://id.portalgaruda.org. (diakses 14 Januari 2017).

Damarany, P.,M.S.Fachrul dan W.Astono. 2009. Kajian Kualitas Air Sungai Cipinang Bagian Hilir Ditinjau dari Parameter BOD dan DO menggunakan Model Qual2E. Jurnal Teknologi Lingkungan.Vol 5 No 2. Fakultas Teknik Lingkungan Universitas Trisakti. Jakarta.

Djoharan, V.,E. Riani dan M. Yani. 2018. Analisis Kualitas Air dan Daya Tampung Beban Pencemaran Sungai Pesanggrahan di Wilayah Provinsi DKI Jakarta.Jurnal Pengelolaan Sumber Daya dan Lingkungan.IPB. Bogor. https://media.neliti.com

Mahyuddin., Soemarno dan T.B. Prayoga. 2015. Analisis Kualitas Air dan Strategi Pengendalian Pencemaran Air Sungai Metro di Kota Kepanjen Kabupaten Malang.Jurnal Pembangunan dan Alam Lestari. Universitas Brawijaya. Malang. https://jpal.ub.ac.id. 
Nuriya, H.,Z. Hidayah dan A.F. Syah. 2010. Analisis Parameter Fisika Kimia di Perairan Sumenep Bagian Timur dengan Menggunakan Citra Lansat TM 5. Jurnal Kelautan.Vol.3 No 2.Universitas Trunojoyo. Madura.https://journal.trunojoyo.ac.id.

Rahman, E.C., Masyamsir dan A. Rizal. Kajian Variabel Kualitas Air dan Hubungannya dengan Produktivitas Primer Fitoplankton di Perairan Waduk Darma Jawa Barat. 2016. Jurnal Perikanan Kelautan.Vol VII No.3. Universitas Padjajaran. Bandung. https://jurnal.unpad.ac.id.

Sahabuddin, H.,D.Harisuseno dan E. Yuliani. 2014. Analisa Status Baku Mutu Air dan Daya Tampung Beban Pencemaran Sungai Wanggu Kota Kendari. Jurnal Teknik Pengairan. Vol 5 No.1. Universitas Brawijaya. Malang.

Sasongko, E.B.,E.Widiastuti dan R.E. Priyono. 2014. Kajian Kualitas Air dan Penggunaan Sumur Gali oleh Masyarakat di Sekitar Sungai Kaliyasa Kabupaten Cilacap.Jurnal Ilmu Lingkungan. Volume 12. Program Studi Ilmu Lingkungan. Universitas Diponegoro. Semarang.

Wikipedia. 2016. Sungai Cisadane. http://www.wikipedia.org. (diakses 27 Mei 2016).

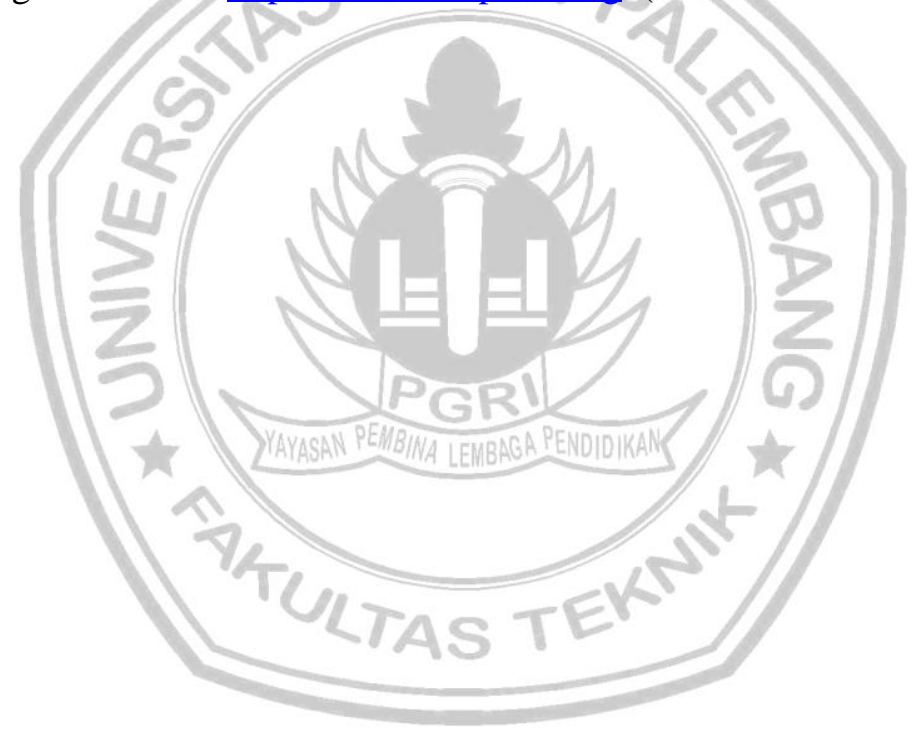

